\title{
CEsifo \\ WORKING

\section{Frontloaded Income Taxation of Old-Age Pensions: For Efficiency and Fairness in a World of International Labor Mobility}

Bernd Genser, Robert Holzmann 


\section{Impressum:}

CESifo Working Papers

ISSN 2364-1428 (electronic version)

Publisher and distributor: Munich Society for the Promotion of Economic Research - CESifo $\mathrm{GmbH}$

The international platform of Ludwigs-Maximilians University's Center for Economic Studies and the ifo Institute

Poschingerstr. 5, 81679 Munich, Germany

Telephone +49 (o)89 2180-2740, Telefax +49 (o)89 2180-17845, email office@cesifo.de

Editors: Clemens Fuest, Oliver Falck, Jasmin Gröschl

www.cesifo-group.org/wp

An electronic version of the paper may be downloaded

- from the SSRN website: $\quad$ www.SSRN.com

- from the RePEc website: $\quad$ www.RePEc.org

- from the CESifo website: www.CESifo-group.org/wp 


\title{
Frontloaded Income Taxation of Old-Age Pensions: For Efficiency and Fairness in a World of International Labor Mobility
}

\begin{abstract}
Strong evidence shows that the existing pattern of cross-border pension taxation in OECD countries and beyond is extremely diverse and inconsistent, generating a double fairness dilemma for individuals and countries alike. This paper argues that this dilemma cannot be solved within the current network of double-taxation treaties. Instead, it proposes a new approach for the taxation of old-age pensions in a world of high and increasing cross-border mobility of workers and pensioners. The paper demonstrates that a coordinated move to frontloaded pension taxation and exclusive source taxation would pave the way for an international pension tax order that eliminates the double fairness dilemma. An additional innovative element of frontloaded pension taxation is presented: the decoupling of individual tax assessment and tax payment, which may help curb political opposition against frontloaded pension taxation and smooth transitional effects after its introduction.
\end{abstract}

JEL-Codes: H240, H550, H870, F220.

Keywords: pension taxation, international taxation, international migration, double taxation convention.

\author{
Bernd Genser \\ Department of Economics \\ University of Konstanz / Germany \\ bernd.genser@uni-konstanz.de
}

\author{
Robert Holzmann \\ Fellow of the Austrian Academy of Sciences \\ (Vienna/Austria) \& Honorary Professor of \\ Economics at the Centre of Excellence in \\ Population Ageing Research, University of \\ New South Wales (Sydney/Australia) \& the \\ Social Security Research Centre, University of \\ Malaya (Kuala Lumpur/Malaysia) \\ robert.holzmann@gmail.com
}

\section{December 2018}

Paper presented at the CESifo Economic Studies Conference "New Perspectives on Tax Administration Research," November 2-3, 2018. We owe thanks to the participants of the conference for helpful comments and critical remarks on the presentation, which is based on a first draft published as a University of Konstanz Working Paper (Genser and Holzmann 2018b). 
In many OECD countries the taxation of old-age income was an issue in recent tax reforms. Several reasons arise for this new focus of tax policy. First, longer pension periods due to aging and generous retirement rules have increased the number of pensioners and the share of old-age income in the national income tax base. Second, many countries implemented deferred taxation of statutory and occupational pensions, following a recommendation by the European Commission that was released as a byproduct of the Commission's initiatives to ensure the portability of old-age pensions for migrants. Finally, pension reforms and the move toward multipillar systems have increased the variety of old-age income sources and tax policy has frequently legislated specific tax rules for these new forms of pensions.

An OECD stocktaking of old-age pensions reveals a three-pillar mix of public, occupational, and personal retirement income provisions with expanding new components that were introduced to cope with the fiscal pressure of the mandated pension scheme (OECD 2017). Moreover, countries particularly supported new forms of occupational and personal retirement savings through tax preferences or direct subsidies. As a matter of fact, the taxation of different forms of retirement savings has created substantial deviations from the principle of comprehensive income taxation, still regarded as the benchmark income tax system across OECD member countries. The erosion of the comprehensive income standard by selective elements of expenditure taxation generates inconsistencies in old-age income taxation; these are the source of unfairness in pension taxation among pensioners who are enrolled in different pension schemes or who use the space for strategic pension planning.

Increasing international mobility of workers and retirees is another source of interpersonal inequity. ${ }^{4}$ Following the blueprint of the OECD model convention to prevent double taxation on income and wealth, the existing network of bilateral double taxation treaties pays attention to cross-border pension benefits (see Annex 2), but these rules do not exclude interpersonal inequities between recipients of domestic and cross-border pension benefits. The international treaty network also generates international inequities among signatory states, which are unable to recoup income tax revenue losses due to deductibility of pension contributions if pension savers emigrate.

To address the double fairness dilemma - among individuals and among countries - the paper is organized as follows. Section 2 offers evidence that the existing pattern of pension taxation is extremely diverse and inconsistent. Section 3 explains (i) why diverse forms of national pension taxation and residence taxation of cross-border pension benefits are responsible for interpersonal and international equity gaps, and (ii) why unilateral and/or bilateral approaches to solve the double fairness dilemma in line with the current OECD double taxation convention will not prove successful. Section 4 presents a new approach of frontloaded pension taxation that, when combined with exclusive source taxation, eliminates the fairness dilemma for individuals and countries. As an additional innovative element of frontloaded pension taxation, the section discusses the separation of individual frontloaded pension tax

\footnotetext{
${ }^{4}$ A precondition for the taxation of cross-border pensions is, of course, that pensions in disbursement and pensions rights in accumulation are in a first instance made portable between countries. The instruments to make them fully portable include agreements at bi- and multilateral level, the use of transnational providers, and the redesign of benefits. See Holzmann and Koettl (2015), Holzmann (2017), and Holzmann (2018).
} 
assessment and income tax payment as a potential cushion when the new system is introduced. The final section summarizes the findings and raises the question of whether the "multiple instruments" approach is a suitable vehicle to establish a consistent international tax order for cross-border pension taxation.

\section{The state of taxation of cross-border pensions}

Income taxation in most OECD countries is codified according to the Schanz/Haig/Simons principle of comprehensive income taxation, which regards any annual increase in personal wealth as taxable income. This is uncontroversial for individual pension wealth, which is accumulated in financial institutions like pension funds, insurance companies, or banks, and which increases an individual's ability to pay and should therefore be taxed as a component of comprehensive income. Economically, this is also true for notional pension wealth within a statutory or mandatory occupational pension system, because individual pension claims under these systems also increase a person's ability to pay, although pension benefits are not capitalfunded but financed on a pay-as-you-go basis. In reality, perceived differences between funded and unfunded pensions have led to a different tax treatment of the respective pension benefits.

To compare national pension tax practices, this analysis makes use of the three phases of the capital accumulation cycle in which income taxes can or should be levied: capital savings, returns on accumulated capital, and capital withdrawals. Technically, comprehensive taxation of capital income can be characterized by a T-T-E income tax, where $\mathrm{T}$ indicates that the respective income flow is taxed at the going tax rate and $\mathrm{E}$ indicates that it is tax exempt. With respect to old-age pensions, comprehensive income taxation T-T-E would require that income used to accumulate pension wealth by contributing to a pension system should be taxed; growing pension claims as returns to pension wealth should be taxed as well; but withdrawals from pension wealth should be tax-exempt. In contrast to the comprehensive income principle, most national income tax codes tax pay-as-you-go-financed pensions E-E$\mathrm{T}$, which implies exempting pension contributions to and returns on pension wealth and taxing pension benefits as withdrawals from pension wealth. The coexistence of T-T-E and EE-T as forms of pension taxation reflects the long-lasting dispute among public economists to tax capital income uniformly and consistently according to either the Schanz/Haig/Simons principle (T-T-E) or the Fisher/Kaldor principle (E-E-T). But it is also backed by the legalistic view of tax practitioners and tax lawyers, who define statutory pensions as (deferred) labor income and funded occupational and personal pensions as capital income. In their view the preferential E-E-T treatment of benefits from unfunded pensions in comparison to the double taxation of funded pensions under T-T-E is not discriminatory and does not contradict the ability-to-pay principle.

Table 1's survey of pension taxation in 49 countries shows a broad variety of tax rules for different forms of pensions. To capture the different tax rules, the terms $t$ and $s$ are used to indicate that in a certain phase of the pension cycle a lower tax rate $\mathrm{t}<\mathrm{T}$ or even a subsidy rate $\mathrm{S}$ is applied. In this sample, a majority of countries apply pure expenditure taxation (E-E-T) and none of them comprehensive income taxation (T-T-E) to statutory pensions. A few of them impose a slightly higher income tax burden, but many offer additional tax preferences to statutory pensions, down to complete tax exemption across all three phases of the pension 
cycle. Sweden is the only country to have a pension tax relief that exceeds full deduction of social security contributions from the personal income tax base by granting a full income tax credit for these contributions. The taxation of occupational and personal pensions reveals a similar pattern, with a less dominant cluster of countries using E-E-T. But columns 3 and 4 also exhibit a significantly broader scope of complexity, reaching from comprehensive income taxation down to full exemption of occupational as well as personal pensions over all three phases of the pension cycle. In addition to the different forms of tax preferences presented in Table 1, country-specific personal pension schemes are often linked with direct financial incentives ${ }^{5}$ granted to encourage voluntary enrolment in supplementary pension saving by further reducing the individual pension tax burden.

Table 1: Income taxation of pensions in OECD countries ${ }^{1 /}$

\begin{tabular}{|l|l|l|l|}
\hline \multicolumn{1}{|c|}{$\begin{array}{c}\text { Tax } \\
\text { Regime }\end{array}$} & \multicolumn{1}{|c|}{ Statutory Pension } & \multicolumn{1}{|c|}{ Occupational Pension $^{2 /}$} & \multicolumn{1}{|c|}{ Personal Pension $^{2 /}$} \\
\hline T-T-E & & NZ, TR & NZ, TR \\
\hline T-t-E & & AU, DK & AU \\
\hline T-E-t & & & DE \\
\hline t-T-E & & BE, HR, NO & SK \\
\hline t-E-T & CA, FR, GB, MT, NL & FR & AT, FI, HR, NO \\
\hline t-t-t & & DK, LV, SE & DK \\
\hline E-t-T & & LV, PL & AT, HU, US \\
\hline T-E-E & & AU & AU \\
\hline t-t-E & & AT, BE, FR, LU, MT, PT & AT, BE, FR, MT, PT \\
\hline t-E-t & CH, DE, EE, LI, NO, & CA, CH, ES, GR, HR, IS, \\
\hline E-E-T & AT, BE, CH, CY, DE, DK, & CA, CH, ES, FI, DE, GR, & NL, PL, SE, SI, US \\
\hline ES, FI, GR, HR, IR, IS, IT,, & HR, IS, NL, SI, US & \\
\hline E-t-t & CZ, MK, PL, RO, SI, SK & & IT, LV \\
\hline s-E-T & SE & IT & CZ, EE, \\
\hline t-E-E & AL, HU, LT, ME & CZ, HU & CY \\
\hline E-t-E & ME & CY & GB, IR, LU, PL, RO \\
\hline E-E-t & LI, LV, PT; TR, US & EE, GB, IR, IS, RO & BG, LT \\
\hline E-E-E & AM, AZ, BG, BY, GE, MC, & BG, SK & \\
\hline
\end{tabular}

Source: IBFD (2017), OECD (2015), and Genser and Holzmann (2018a).

Note: ${ }^{1 /}$ Country abbreviations follow the two-letter ISO 3166 code listed in Annex 1.

2/ The OECD (2015) study does not cover AL, AM, AZ, BY, GE, LI, MD, MC, ME, RS, RU, or UA.

The complexity of the tax treatment of pensions increases when individuals earn pension claims in different countries and pension benefits are paid across borders. The avoidance of international double taxation of cross-border pensions is codified in bilateral double taxation treaties. Although these treaties usually follow the recommendations of the OECD model tax

\footnotetext{
${ }^{5}$ For further remarks on these direct financial incentives see OECD (2015), section 7.
} 
convention, room exists for variance in income tax assignments for different forms of foreign income. Table 2 reveals the tax assignment of cross-border pension flows in treaties signed by Germany. There is a marked dominance of the residence principle, but statutory pensions are frequently assigned to the source country exclusively. Shared tax assignments allowing for limited source country tax credited in the residence country are rare.

A closer look at the bilateral network of double taxation treaties reveals three fundamental complexities of cross-border pension taxation. First, Germany taxes cross-border pension benefits differently for different forms of retirement income. Second, Germany taxes inbound cross-border pension benefits differently depending on the source country. Third, Germany taxes outbound pension benefits differently depending on the residence country of the pensioner.

Table 2: Tax assignment of cross-border pensions in German double taxation treaties ${ }^{1 /}$

\begin{tabular}{|l|l|l|l|}
\hline Tax assignment & \multicolumn{1}{|c|}{ Statutory } & \multicolumn{1}{c|}{ Occupational } & \multicolumn{1}{c|}{ Personal } \\
\hline $\begin{array}{l}\text { Exclusive residence } \\
\text { taxation }\end{array}$ & $\begin{array}{l}\text { CA, CH, CZ, EE, } \\
\text { ES, FI, GB, GR, } \\
\text { HU, IR, IT, LU, } \\
\text { PT, SI, SE, US }\end{array}$ & $\begin{array}{l}\text { EE, ES, FI, FR, } \\
\text { GB, GR, HU, IR, } \\
\text { IT, LU, MT, NL, } \\
\text { PL, SE, SI, US }\end{array}$ & $\begin{array}{l}\text { EE, ES, FI, FR, GB, } \\
\text { GR, HU, IR, IT, LU, } \\
\text { SI, US }\end{array}$ \\
\hline $\begin{array}{l}\text { Exclusive source taxation, PT, SE, } \\
\text { progression proviso in } \\
\text { residence country }\end{array}$ & $\begin{array}{l}\text { AT, BE, DK, FR, } \\
\text { IT (citizens), MT, } \\
\text { NL, PL, SE }\end{array}$ & FR (mandatory) & \\
\hline $\begin{array}{l}\text { Nonexclusive source } \\
\text { taxation, residence } \\
\text { taxation with tax credit }\end{array}$ & & CA, DK & CA, DK (rents) \\
\hline
\end{tabular}

Source: Genser and Holzmann (2018a), Wellisch et al. (2008), and tax treaties.

Note: ${ }^{1 /}$ The country abbreviations follow the two-letter ISO 3166 code listed in Annex 1.

Tables 1 and 2 provide strong evidence that application of different tax rules within and between countries for different forms of pensions violates horizontal equity, motivates strategic pension planning, and is a source of interpersonal fiscal unfairness. In addition, inconsistent and uncoordinated assignments for income taxes on retirement income also create fiscal unfairness between countries, and induce strategic migration of pensioners as well as international competition in pension taxation.

The scope of this double fairness dilemma has grown in the past and will become more serious in the decades ahead because working abroad or emigrating for retirement is now facilitated by the fundamental right of free movement of persons within the EU (article 3(2) of the EU Treaty) and the improved portability of benefits between OECD countries and within key migration corridors.

Table 3 highlights this development for Germany. The number of pensioners living abroad on a German pension reached 1.7 million in 2013 (or 6.85 percent of all German pensions). 
Pensioners with a non-German pension living in Germany may receive a pension for insurance periods abroad as outward or inward labor migrants (as do 1.1 million pensioners, or 4.21 percent of all pensioners with a German pension). This gives a total of 2.8 million potential recipients (or 11.1 percent) of a cross-border pension. Yet these numbers reflect the labor mobility of the past and do not include the higher pan-European labor mobility since the 1990s. Estimates for the European Union of the future share of pensions paid abroad to the current workforce arrive at some 15 to 25 percent (Holzmann 2015). Moreover, the number of individuals who receive retirement income from national as well as cross-border entitlements should be much higher for smaller and less developed countries.

Table 3: Recipients of statutory German pensions - in Germany and abroad

\begin{tabular}{|l|c|c|c|}
\hline $\begin{array}{l}\text { Number of pensioners in millions } \\
\text { (\% of total pensioners) }\end{array}$ & $\mathbf{2 0 1 3}$ & $\mathbf{2 0 1 0}$ & $\mathbf{2 0 0 5}$ \\
\hline Total non-German pensioners & $2.562(100 \%)$ & $2.367(100 \%)$ & $2.032(100 \%)$ \\
\hline - living in Germany & $1.059(41.3 \%)$ & $0.944(39.9 \%)$ & $0.774(38.1 \%)$ \\
\hline - living outside Germany & $1.503(58.7 \%)$ & $1.423(60.1 \%)$ & $1.258(61.9 \%)$ \\
\hline Total German pensioners & $22.602(100 \%)$ & $22.646(100 \%)$ & $22.452(100 \%)$ \\
\hline - living outside Germany & $0.222(0.98 \%)$ & $0.206(0.91 \%)$ & $0.170(0.76 \%)$ \\
\hline Total pensioners & $25.164(100 \%)$ & $25.013(100 \%)$ & $22.484(100 \%)$ \\
\hline - living outside Germany & $1.725(6.85 \%)$ & $1.629(6.51 \%)$ & $1.427(5.83 \%)$ \\
\hline $\begin{array}{l}\text { - non-German pensioners } \\
\text { living in Germany }\end{array}$ & $1.059(4.21 \%)$ & $0.944(3.77 \%)$ & $0.774(3.44)$ \\
\hline $\begin{array}{l}\text { - potential recipients of } \\
\text { cross-border pensions }\end{array}$ & $2.784(11.1 \%)$ & $2.573(10.3 \%)$ & $2.201(9.8 \%)$ \\
\hline
\end{tabular}

Source: Genser and Holzmann (2016b), based on Eurostat Online Database (June 2015).

Countries negatively affected by this double fairness dilemma are free to react in two ways: by an appropriate income tax reform at the national level and/or by renegotiating double taxation treaties at the international level. Uni- and bilateral approaches are highly unlikely to be promising strategies, at least in the short run. This scepticism is not only based on the experience that renegotiating double taxation treaties is extremely complicated and timeconsuming. The next section argues that the interaction of deferred income taxation of old-age pensions is incompatible with the current design of the OECD model tax convention and the network of double taxation treaties influenced by the model convention.

\section{The incompatibility of deferred income taxation and OECD model tax convention}

The OECD model tax convention addresses pensions in Articles 18 and 19 (see Annex 2). According to Article 18, pensions benefits disbursed across borders in consideration of past employment are taxable only in the residence country of the recipient. The article contains, however, a provision clause for cross-border pension benefits paid out to a recipient in the residence country by a public body or by a publicly created fund. In this case Article 19 states that the pension benefit is taxable in the source state, unless the recipient is also a national of the resident state. 
According to the commentary on Article 18 concerning the taxation of pensions (OECD 2014, 292ff), the dominance of the residence principle is primarily motivated by administrative arguments. On one hand, the residence state of the recipient of a foreign pension is assumed to be in a better position than the source state to take into account the recipient's overall ability to pay, which depends on his worldwide income and personal circumstances. On the other hand, residence taxation is supposed to ease the tax compliance of the recipient of foreign pension benefits because tax obligations are concentrated on the residence country only. Source taxation on public pensions according to Article 19 (OECD 2014, 310ff) was originally a minor byproduct of income taxation of public employees inherited from traditional rules of international courtesy. However, the scope and fiscal importance of Article 19 has increased with the growth of the public sector in many countries and with the extension of public activities abroad. Moreover, the model tax convention of 1977 changed the assignment of taxes on public salaries and wages (and subsequent pensions) from a potential to an exclusive right of the source state.

Deferred income taxation of pension benefits of migrants according to Article 19 implies that the source state must keep track of a nonresident's ability to pay, which contradicts the first motive for Article 18. Furthermore, deferred pension taxation implies that pensioners have to comply with the tax authorities of their residence country as well as of those source countries who pay out pension benefits in line with Article 19. Unavoidable cross-border compliance contradicts the second motive for Article 18.

From an economic perspective it is important to recognize that the assignment of pension taxation in the OECD model tax convention is restricted to phase 3 of the pension cycle, when pension benefits are paid out across the border. The possibility of taxing pensions already while pension wealth is accumulated is neither addressed in the model convention nor in the elaborate commentaries on Articles 18 and 19 (OECD 2014). An immediate consequence of this gap is that pensions pre-taxed in the source country during the accumulation periods will be double-taxed if the residence state taxes cross-border pension benefits.

This undesirable result can, however, be avoided if the source country's tax code determines deferred income taxation on pensions, as proposed by the Eurpopean Commission. Under an E-E-T regime no income tax is levied when contributions are paid and when pension wealth earns returns. Income tax only becomes due when pension benefits are paid out. For a pensioner who emigrates after retirement, and for whom pension benefits are taxable exclusively in the immigration country, double taxation of pension benefits cannot occur. But simultaneously the total income tax payment goes to the resident state and the income tax revenue of the benefit-paying source state is zero.

Income tax deficits as a consequence of Article 18 may have been a motive for reforming Article 19, although this is not mentioned explicitly in the OECD commentaries. Countries feel entitled to tax earned income used for pension saving while workers have been residents. Deferred taxation of pension benefits implies that the right to tax pension benefits after migration is assigned to the new residence country and the source country has to abandon this right. Some evidence suggests that fiscal pressure induces source counties to tax migrants (i) implicitly by maintaining income tax regimes that deviate from deferred pension taxation, or (ii) explicitly by expanding source taxation in their double taxation treaties. 
Table 4: Income tax on migrants for different tax regimes and tax assignments

Tax assignment

Tax regime in $\mathbf{A}$

A1 income

A1 pension saving

A1 tax base

A1 income tax

A2 pension benefit

A2 tax base

A2 income tax

\section{Credit method in B}

B2 tax base

B2 income tax

B2 income tax

credit

\section{Net present values}

total income

total tax burden

tax revenue in $\mathrm{A}$

tax revenue in $\mathrm{B}$

\section{Residence principle}

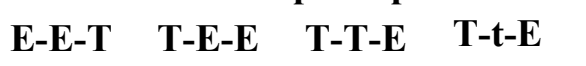

Source principle

$\begin{array}{cccc}\text { E-E-T } & \text { T-E-E } & \text { T-T-E } & \text { T-t-E } \\ 120 & 120 & 120 & 120 \\ 24 & 24 & 24 & 24 \\ 96 & 120 & 120 & 120 \\ 28,8 & 36 & 36 & 36 \\ 48 & 48 & 48 & 48 \\ 48 & 0 & 24 & 12 \\ 14,4 & 0 & 0 & 0\end{array}$

$\begin{array}{cccccccc}48 & 48 & 48 & 48 & 48 & 48 & 48 & 48 \\ 14,4 & 14,4 & 14,4 & 14,4 & 14,4 & 14,4 & 14,4 & 14,4 \\ & & & 0 & & & & 0\end{array}$

$\begin{array}{lll}14,4 & 0 & 0\end{array}$

$\begin{array}{lll}0 & 0 & 0\end{array}$

$\begin{array}{cccccccc}128 & 128 & 128 & 128 & 128 & 128 & 128 & 128 \\ 38,4 & 45,6 & 52,8 & 49,2 & 38,4 & 45,6 & 52,8 & 49,2 \\ 28,8 & 36 & 40,8 & 38,4 & 38,4 & 36 & 40,8 & 38,4 \\ 9,6 & 9,6 & 9,6 & 9,6 & 0 & 9,6 & 9,6 & 9.6\end{array}$

Source: Authors' calculations.

Note: Parameter values: labor income in A 120 , pension contribution rate $20 \%$, income tax rate in A and $\mathrm{B} 30 \%$, normal return rate $50 \%$, excess return rate $50 \%$, A1 working period in country A, A2 retirement period in country A, B2 Retirement period in country B.

Table 4 presents a broader set of treaty cases that illustrate the double fairness dilemma and the constrained capability of the OECD model tax convention to solve it. For a given set of parameters, the table illustrates the interaction of four different tax regimes in state A and two assignments on income taxation for a pensioner who migrates to state $\mathrm{B}$ after retirement. For state $\mathrm{B}$, it is assumed that, in line with the OECD model tax convention, double taxation of benefits is eliminated by granting an income tax credit for income tax on pension benefits paid in state A. For the interpretation of the numerical values of Table $4,{ }^{6}$ it is helpful to start out from the E-E-T tax regime and source taxation of pension benefits in state A. In net present values, the total tax burden of the migrant is exactly 30 percent. Under most other regimes the tax burden is higher, reflecting international double taxation because the tax credit granted by the immigration state $\mathrm{B}$ is restricted to benefit taxes in state A but excludes pre-taxation of pension contributions or pension wealth returns. Deferred income taxation (E-

\footnotetext{
${ }^{6}$ It is helpful to keep in mind that under the source principle, pension tax revenue in state A replicates the tax revenue situation in the no-migration case. The numbers also show that the tax burden under an E-E-T expenditure regime is smaller than under a T-T-E comprehensive income tax regime, but higher than under a TE-E prepaid expenditure tax system, which keeps excess returns on pension wealth tax-free.
} 
E-T) under the residence principle in state A also avoids international taxation, so the revenue from benefit taxation in state $\mathrm{A}$ is zero under this regime. The last line also reveals that the revenue of the immigration state is maintained under the different forms of pre-taxed pensions, because the credit method only hits in the case of deferred pension taxation in state A when state B revenue shrinks to zero. Whenever source states try to avoid the substantial revenue loss associated with deferred pension taxation under the residence principle by pretaxing pensions, this comes at the cost of international double taxation. The problem of this double fairness dilemma is that the model tax convention offers no way to cope appropriately with this double taxation phenomenon, because states are free to tax pension income along the whole pension cycle.

\section{Income taxation with pre-taxed pension income}

To address the incompatibility outlined in the prior section, it is propose that frontloaded taxation of pensions be codified in national income taxation and source taxation of pensions be codified in double-taxation treaties. To implement this, three pension tax payment options are offered. $^{7}$

\subsection{The starting position}

The starting point for this new conceptual framework of pension taxation is the existence of two unsolved problems in the prevailing architecture of existing pension tax systems. First, there is the simultaneous orientation of income tax equity along two mutually exclusive equity standards: comprehensive income taxation and expenditure taxation. ${ }^{8}$ These standards imply different time patterns of capital income taxation over the accumulation and utilization of capital. The Schanz/Haig/Simons principle requires income taxation while capital wealth accrues, viz. T-T-E, whereas the Fisher/Kaldor principle defers taxation until capital wealth is used for consumption, viz. E-E-T. The Fisher/Kaldor approach forgoes the double taxation of saving and establishes intertemporal neutrality for consumption decisions. Countries typically apply comprehensive income taxation for capital income not related to retirement but apply various forms of Fisher/Kaldor-type taxes on different forms of retirement income, as shown in Table 1. Pure expenditure taxation is frequently applied for statutory pensions, less frequently for occupational pensions. Highly differentiated and country-specific forms of taxation are applied to personal pensions. Second, tax assignment and balancing methods in double taxation treaties that try to avoid double taxation of pensions are codified only for cross-border pension benefit flows and ignore that pensions may already have been pre-taxed when pension wealth was accumulated.

\subsection{The proposal}

\footnotetext{
${ }^{7}$ For the origins and details of the proposal, see Genser (2015), Holzmann (2015), and Genser and Holzmann (2016a, 2016b, 2018a).

${ }^{8}$ The inconsistencies in cross-border taxation of pensions are grounded in theoretical ambiguities of taxation of pensions and their implementation in the national context. For the state of the theory of pension taxation and the implementation of pension taxation in key industrialized countries, consult Holzmann and Piggott (2018). Mirrlees (2010) offers broader perspectives on the taxation of labor and capital and calls for an integrated approach for the design of pensions and their taxation.
} 
To avoid these two problems, it is proposed to require that:

(i) pensions are taxed according to the Fisher/Kaldor principle; and

(ii) avoiding double taxation should account for pension taxes over the whole pension cycle.

With respect to the first requirement, the European Commission's recommendation in favor of deferred income taxation is not simply repeated; instead, the argument makes use of a fundamental equivalence property of the Fisher/Kaldor approach. The non-neutrality of comprehensive income taxation cannot only be avoided by expenditure taxation, viz. E-E-T, but also by a corresponding frontloaded income tax regime, viz. T-t-E, which shares the intertemporal neutrality property of the backloaded Fisher/Kaldor-type expenditure tax for an appropriately chosen reduced tax rate $t$ and then is economically equivalent under a set of simplifying assumptions. Under a T-t-E regime, income spent on pension savings is taxed when contributions are made and exempted when pension benefits are withdrawn from accumulated pension wealth. Moreover, returns on pension wealth are only liable to tax if they exceed the normal returns, which are tax-exempt. This partial income tax exemption of returns is indicated by $\mathrm{t}<\mathrm{T}$. An immediate consequence of this partial exemption is that the tax liability under expenditure taxation, backloaded as E-E-T or frontloaded as T-t-E, is smaller than under comprehensive income taxation T-T-E.

With respect to the second requirement, the time pattern of T-t-E taxation is made use of. Pensions are pre-taxed in the source country, while pension benefits are exempt. To avoid double taxation of cross-border benefits, it is necessary to exempt pension benefits in the residence country as well. Compared to deferred income taxation, under T-t-E pension tax revenue losses cannot occur when individuals migrate as retirees nor when they emigrate before retirement, as their pension wealth has been appropriately taxed upon accrual.

This reform proposal of pension taxation solves the double fairness dilemma. If states affected by migration switch from deferred income taxation to frontloaded expenditure taxation, and tax labor income as well as pension wealth accruals, then migration does not erode the source state's tax base. Whenever a migrant leaves, future pension benefits have been fully pre-taxed and tax revenue fairness among states prevails. If states affected by migration apply frontloaded pension taxation and exempt all (domestic as well as cross-border) pension benefits of resident pensioners, then international double taxation of pensions is eliminated as well.

Some states are aware of the double fairness dilemma but are reluctant to give up deferred pension taxation, hoping instead for an appropriate revision of double taxation treaties. However, it should be emphasized that pre-taxation offers some additional attractive features that facilitate pension taxation nationally as well as internationally:

(i) Pre-taxation of pensions implies that migration no longer causes recouping pressure, even under the existing network of double taxation treaties.

(ii) Pre-taxation of pensions avoids international double taxation of pensions if double taxation treaties assign the right to tax cross-border pension benefits to the source state rather than to the residence state. 
(iii) Pre-taxation of pensions implies that no income tax is due for pension benefits paid out to nonmigrants as well as to migrants. This is a substantial relief in tax compliance and tax administration because pensioners will not have to file tax returns for the rest of their lives if they receive pensions benefits from more than one pension fund.

(iv) Pre-taxation of pensions implies that the income tax authority accounts for the relevant personal circumstances of the income earner and his ability to pay under unlimited tax liability as a resident of the source country.

(v) Equity norms, on which progressive income tax schedules are based, will no longer be eroded by postponed pension taxation, which is particularly beneficial for high income earners, who are usually taxed at substantially lower tax rates after retirement. ${ }^{9}$

(vi) The problem of taxing pension benefits under limited tax liability in the source state after migration is avoided, because pensions were already pre-taxed under unlimited tax liability in the emigration state.

(vii) Pensioners would only have to comply with the income tax authority in the residence state after migration if they earn other taxable income beside pension benefits in the residence country.

(viii) If pensions are pre-taxed and pension benefits are not taxable, pensioners are offered an incentive to supplement their pension benefits by tax free labor or rental income as long as these additional earnings do not exceed the personal income tax allowance.

(ix) Administration and compliance costs of pre-taxing pension will be lower than under deferred pension taxation because monitoring costs on deductible contributions can be saved as well as tax assessment costs for retirees. Keeping track of taxable excess returns on pension wealth may be kept low if these returns are treated as capital income to be taxed at a flat rate under a dual income tax.

\subsection{Three tax payment options}

The frontloaded pension tax approach sketched above suggests that tax liabilities must be cleared immediately upon income tax assessment. But this is not a necessary consequence. The tax authority may accept deferred down payment of the assessed tax liability in just the same fiscal way as expenditure taxation defers taxation of saved income. Deferred down payment of tax debt is neutral for the government fiscal position as long as the present value of deferred tax payments is equal to the present value of the assessed tax liability. For this reason, three proposals are presented that complement the T-t-E frontloaded pension tax regime by decoupling the tax statement of the tax authority and the prescription of tax payment.

(i) The frontloaded tax payment option requires that tax liabilities are immediately settled when they occur. This does not necessarily mean an additional tax payment of the pension saver. Taxes can be settled if the tax liability is paid out of the individual

\footnotetext{
${ }^{9}$ Based on data by HM Revenue and Customs (2018), Johnson calculates that 40 percent of the combined cost of income tax relief from exempting contributions to registered pension schemes plus National Insurance relief on employers contributions of GBP 47,000 in 2016/17 went to the top 10 percent of income earners (Johnson 2018). The net cash-flow revenue loss for the British budget is only slightly reduced by the income tax on pension payments (GBP 13,500,000 in 2016/17) because a further pension-related income tax relief of GBP 7,900,000 is granted for investment income of pension funds.
} 
contribution to the pension system, which implies that pension wealth accumulation is reduced by the tax factor (1-T). The same procedure can be applied to settle the income tax liability on excess returns. Pension funds are obliged to pay income tax to the tax authority and pension wealth returns are reduced by the tax factor (1-t). No income tax is due when pension benefits are disbursed after retirement. Since all income tax liabilities on pension wealth are settled immediately, no revenue loss arises if the pension saver emigrates as a worker or a pensioner.

(ii) Under the deferred tax payment option, tax liabilities are assessed according to the Tt-E regime until retirement and then turned into a tax annuity that must be paid to the tax administration in line with the disbursement of the monthly pension benefits (Holzmann 2015). The approach combines the formal frontloading of tax assessment (T-t-E) with a material back-loading (E-E-T) of tax payment and defers the net income loss by cutting net pension benefits. If a pension saver emigrates before retirement but the gross pension assets remain in the source country then the future tax annuity of the migrant can be withheld when pension benefits are paid out and passed on to the source country's budget in the same way as for a resident retiree. If the pension wealth is transferred abroad upon migration, then the accumulated tax liability becomes due as an exit tax that is also paid by the pension fund, and the migrant's transferable pension wealth is reduced accordingly. If a pensioner dies before the accumulated tax liability is redeemed, then again the pension fund is required to step in and settle the open tax debt.

(iii) Under the distributed tax payment option the payments of the accumulated tax liability are spread evenly across the whole pension cycle by charging an appropriate constant rate $t^{*}$ on contributions, pension wealth returns, and pension benefit payouts. The rate t* should be chosen in a way to balance the expected aggregate present value of tax payments and the expected present value of the frontloaded pension tax liability. Balancing tax payments and tax liability at the individual level should be left to a recalculation of the monthly payment upon retirement by means of a supplemental tax annuity, which could be either an individual surtax or a tax decrement on t*. Emigration or death of the pensioner should be settled by the pension fund as sketched above. A constant tax payment rate $t^{*}$, which should roughly be one-half the average income tax rate, might increase political support because the net income losses as well as the tax revenue inflows level out over the lifespan of individuals. Moreover, $t^{*}$ increases the toolbox of tax policy and mitigates the fiscal transition effects that accompany the switch from deferred to pre-taxed pension taxation.

Decoupling of tax assessment and tax payment have no direct effect on migration and tax assignment in double taxation treaties. The exclusive right to tax pension benefits in the source county and to exempt them when pensions are pre-taxed precludes international double taxation. Unlimited income tax liability in the source country when income is earned and pension wealth is accumulated as resident and unlimited tax liability in the new residence country after migration are in full accordance with the objectives of equitable ability to pay and low costs of tax compliance and tax administration. Individual equity with respect to 
residence taxation after migration can be achieved by applying the progressivity proviso in double taxation treaties, ensuring that tax-exempt, cross-border pension benefits increase the income tax rate on other taxable income in the residence country.

\section{$5 \quad$ Concluding remarks}

The taxation of cross-border pensions in a globalized world is characterized by astonishing diversity, complexity, and inconsistency, the fallout of which will increase with rising life expectancy and international mobility of citizens. The present disarray reflects a conceptual gap between social sciences with respect to tax equity in a multicountry setting.

This paper proposes pre-taxation of pensions as a suitable economic concept for global pension taxation, as it accounts for fairness and efficiency at the individual and national level. The analysis shows that pre-taxation of pensions does not constrain national preferences on interpersonal equity and fiscal fairness between states and allows simplification of the international tax order within the existing network of double taxation treaties.

To implement the new concept quickly and consistently, the newly created "Multilateral Instrument" to modify bilateral tax treaties may prove a useful legal tool. But the first step along a reform path should be a discussion within international organizations about whether a redesign of the international tax order on old-age pension taxation is desirable and viable. 
Genser, B. 2015. "Towards an International Tax Order for the Taxation of Retirement Income.” CEPAR Working Paper 2015/25, University of South Wales, Sydney.

Genser, B., and R. Holzmann. 2016a. "The Taxation of Internationally Portable Pensions: Fiscal Issues and Policy Options.” CESifo Working Paper No. 5702, Munich. . 2016b. "The Taxation of Internationally Portable Pensions: An Introduction to Fiscal Issues and Policy Options.” CESifo DICE Report 1-16, 24-29, Munich.

. 2018a. "The Taxation of Internationally Portable Pensions: Fiscal Issues and Policy Options." In The Taxation of Pensions, ed. R. Holzmann and J. Piggott, pp. 443-479, op.cit.

. 2018b. "A Viable International Tax Order for Cross-Border Pensions." Working Paper Series 2018-02, Department of Economics, University of Konstanz, March.

HM Revenue and Customs. 2018. Personal Pensions Statistics. National Statistics Publication, London, September.

Holzmann, R. 2015. “Taxing Pensions of an Internationally Mobile Labor Force: Portability Issues and Taxation Options." CEPAR Working Paper 2015/27, University of New South Wales, Sydney.

. 2017. "Do Bilateral Social Security Agreements Deliver on the Portability of Pensions and Health Care Benefits? A Summary Policy Paper on Four Migration Corridors Between EU and Non-EU Member States." IZA Journal of European Labor Studies 5(17): 1-35.

. 2018. "The Portability of Social Benefits Across Borders." IZA World of Labor: Evidence-based Policy Making. wol.iza.org/articles/the-portability-of-social-benefitsacross-borders/long

Holzmann, R., and J. Koettl. 2015. "The Portability of Pensions, Health, and Other Social Benefits: Concepts and Issues." CESifo Economic Studies 61(2): 377-415.

Holzmann, R., and J. Piggott. 2018. The Taxation of Pensions. CESifo Seminar Series with MIT Press: Cambridge, MA.

International Bureau of Fiscal Documentation (IBFD). 2017. European Tax Handbook 2017. Global Tax Series, IBFD, Amsterdam.

Johnson, M. 2018. "Five Proposals to Simplify Saving." Pointmaker, Centre for Policy Studies, London, August.

Mirrlees, J. 2010. Tax by Design - The Mirrlees Review. Oxford University Press: Oxford.

Organisation for Economic Co-operation and Development (OECD). 2014. Model Tax Convention on Income and on Capital: Condensed Version 2014. OECD Publishing: Paris. 
2015. Stocktaking of the Tax Treatment of Funded Private Pension Plans in OECD and EU Countries. OECD Publishing: Paris.

. 2017. Pensions at a Glance 2017: OECD and G20 Indicators. OECD Publishing: Paris.

Wellisch, D., S. Lorz, K. Thiele, and R. Gahl. 2008. Besteuerung der Altersvorsorge. Nomos, Baden-Baden. 
Annex 1 Two-letter country abbreviations subject to ISO code 3166

\begin{tabular}{|l|l|l|l|l|}
\hline AL Albania & CY Cyprus & GR Greece & MC Monaco & RO Romania \\
\hline AM Armenia & CZ Czech Republic & HR Croatia & MD Moldova & RS Serbia \\
\hline AT Austria & DE Germany & HU Hungary & ME Montenegro & RU Russia \\
\hline AU Australia & DK Denmark & IR Ireland & MK Macedonia & SE Sweden \\
\hline AZ Azerbaijan & EE Estonia & IS Iceland & MT Malta & SI Slovenia \\
\hline BE Belgium & ES Spain & IT Italy & NL Netherlands & SK Slovakia \\
\hline BG Bulgaria & FI Finland & LI Liechtenstein & NO Norway & TR Turkey \\
\hline BY Belarus & FR France & LT Lithuania & NZ New Zealand & UA Ukraine \\
\hline CA Canada & GB United Kingdom & LU Luxembourg & PL Poland & US United States \\
\hline CH Switzerland & GE Georgia & LV Latvia & PT Portugal & \\
\hline
\end{tabular}




\section{Annex 2 OECD model tax convention on income and on capital ${ }^{10}$}

\section{Article 18 PENSIONS}

Subject to the provisions of paragraph 2 of Article 19, pensions and other similar remuneration paid to a resident of a Contracting State in consideration of past employment shall be taxable only in that State.

\section{Article 19 GOVERNMENT SERVICE}

1. a) Salaries, wages and other similar remuneration paid by a Contracting State or a political subdivision or a local authority thereof to an individual in respect of services rendered to that State or subdivision or authority shall be taxable only in that State.

b) However, such salaries, wages and other similar remuneration shall be taxable only in the other Contracting State if the services are rendered in that State and the individual is a resident of that State who:

(i) is a national of that State; or

(ii) did not become a resident of that State solely for the purpose of rendering the services.

2. a) Notwithstanding the provisions of paragraph 1, pensions and other similar remuneration paid by, or out of funds created by, a Contracting State or a political subdivision or a local authority thereof to an individual in respect of services rendered to that State or subdivision or authority shall be taxable only in that State.

b) However, such pensions and other similar remuneration shall be taxable only in the other Contracting State if the individual is a resident of, and a national of, that State.

3. The provisions of Articles 15, 16, 17, and 18 shall apply to salaries, wages, pensions, and other similar remuneration in respect of services rendered in connection with a business carried on by a Contracting State or a political subdivision or a local authority thereof.

\section{Article 21 OTHER INCOME}

1. Items of income of a resident of a Contracting State, wherever arising, not dealt with in the foregoing Articles of this Convention shall be taxable only in that State.

2. The provisions of paragraph 1 shall not apply to income, other than income from immovable property as defined in paragraph 2 of Article 6 , if the recipient of such income, being a resident of a Contracting State, carries on business in the other Contracting State through a permanent establishment situated therein and the right or property in respect of which the income is paid is effectively connected with such permanent establishment. In such case the provisions of Article 7 shall apply.

\footnotetext{
${ }^{10}$ OECD 2014, 34f.
} 